\title{
En memoria del Lic. José Luis Coto Conde
}

\author{
Por
}

\author{
Lic. Luz Alba Chacón León de Umaña \\ Exdirectora del Archivo Nacional
}

Académica de Número, Academia de Geografía e Historia de Costa Rica

Con un sentimiento matizado de dolor y reconocimientos han girado nuestros recuerdos en los últimos días, alrededor de quien fue el amigo y colega: José Luis Coto Conde.

Decir Coto Conde, o don José Luis o simplemente don José, durante el trabajo diario, las sesiones, o las tertulias en el Archivo Nacional y en la Academia de Geografía e Historia de Costa Rica, fue suficiente por muchos años, para aludir al compañero. Y todavía hoy, en la conversación de quienes compartimos aquellos momentos agradables, basta decir don José Luis, para referirnos a él.

Don José Luis nació en San José en un hogar de fuerte raigambre costarricense por su padre y española por su madre. Concluido su Bachillerato en el Liceo de Costa Rica, se recibió de Maestro en la Escuela Normal de Heredia y luego viajó a Chile y Argentina a cursar estudios universitarios en Historia y se graduó de Profesor en su especialidad. Su regreso al país coincidió con los acontecimientos políticos de 1948 y pasados éstos, se le nombró Director del Archivo Nacional, cargo que desempeñó hasta 1980.

Su gestión en esta entidad está enmarcada dentro de un proceso de replanteamiento, ya que las nuevas corrientes archivísticas arribaron a Costa Rica hacia el decenio de 1970 y él con una visión amplia y clara, apoya estas propuestas y comienza en el Archivo una transformación. La llegada a partir de 1972 de equipo y expertos para el área de conservación de documentos y de otros especialistas en organización y legislación archivísticas, el inicio del otorgamiento de beca al personal, el Proyecto piloto para el desarrollo de archivos, marcan ese germen de cambio que lentamente dio sus frutos. La creación de la carrera de Archivística (Universidad de Costa Rica), en 1978, coadyuvó en este devenir. Su inclinación profunda hacia la Historia, lo impulsó a formar parte con gran éxito de varias comisiones conmemorativas patrias, tales como la del Centenario de la Campaña Nacional y el Sesquicentenario de la Independencia de Centro América. Su cualidad de educador nato que heredó de su padre, lo convirtió en un expositor insigne y 
en un ameno comunicador. Escucharlo desarrollar cualquier tema de nuestra historia fue realmente un gozo para el espíritu. Lo mismo puede decirse de su libro "Eran otros tiempos", en el que despliega su sapiencia y sus dotes de investigador. Esta publicación escrita en forma de crónicas, constituye un excelente recurso para asomarse al ayer. Su pensamiento también lo recogen los anales de la Academia de Geografía e Historia de Costa Rica, y los artículos de su autoría junto con los editoriales de la Revista del Archivo Nacional, de la que fue Director por 30 años. . No por casualidad la Sala de Investigacion del Archivo Nacional lleva su nombre. !Hermosa manera de reconocer sus logros!

En la Academia de Geografía e Historia -una de sus instituciones más queridas-, su labor, como Académico de Número y de la Silla Ricardo Fernández Guardia, fue altamente apreciada y en tres períodos fungió como Presidente. Ocupó igualmente en varias oportunidades la vicepresidencia, la tesorería, secretaría y vocalías. Reuniones nacionales e internacionales, históricas y archivísticas, así como la Comisión Nacional de Conmemoraciones Históricas y los Institutos de Cultura Hispánica, San Martiniano y Chile Costarricense, se beneficiaron con sus iniciativas y proyectos. Su labor en estas áreas mereció distinciones. Valga citar: Miembro de Honor de la Academia Costarricense de Ciencias Genealógicas, Miembro Correspondiente de la Asociación Venezolana de Archivistas y de la Academia de Historia de Guatemala.

!Cuántas experiencias singulares podríamos relatar de su condición de amigo! Quienes la disfrutamos, repetimos y repetimos que la obsequió dentro de una entrega y caballerosidad sin reticencias.

Personalmente quedamos en deuda con don José Luis porque fue nuestro mentor, porque nos enseñó las maravillas que custodia el Archivo Nacional y supo eliminar los espacios de dudas, que muchas veces tuvimos sobre el quehacer archivístico e histórico. En fin, nos mostró senderos por donde escuchar los latidos ancestrales que brotan de cada documento.

Hemos recordado con qué convicción se pronunció en favor del 29 de octubre de 1821, como la verdadera fecha de la independencia de Costa Rica del Gobierno Español y, curiosamente, un 29 de octubre 180 años después de aquel suceso, don José Luis entregó su alma a nuestro Dios Eterno y Misericordioso.

Don José Luis puede descansar en paz. Cumplió a cabalidad su misión en esta tierra. 